\title{
Analisis Penggunaan Gelatin Sapi dan Gelatin Babi sebagai Cladding pada Serat Optik untuk Perancangan Sensor Kelembaban
}

\author{
Wafa Faziatus Sholikhah dan Agus Rubiyanto \\ Departemen Fisika, Fakultas Ilmu Alam, Institut Teknologi Sepuluh Nopember (ITS) \\ e-mail: arubi@physics.its.ac.id
}

\begin{abstract}
Abstrak-Sensor kelembaban telah dikembangkan menggunakan serat optik plastik jenis multimode step index. Cladding serat optik diganti dengan lapisan gelatin sapi dan babi di bagian tengahnya sepanjang $3 \mathrm{~cm}$ dan $4 \mathrm{~cm}$ digunakan sebagai sensor. LED ultra bright panjang gelombang $631 \mathrm{~nm}$ digunakan sebagai sumber cahaya dan photodioda sebagai detektor cahaya. Pengukuran sensor diukur dari rentang kelembaban relative $(\mathbf{6 5 - 8 2}) \%$. Hasil pengukuran memperlihatkan sensor hanya dapat digunakan pada kenaikan nilai kelembaban relatif. Sensor dengan cladding gelatin babi panjang kupasan $3 \mathrm{~cm}$ merupakan sensor dengan nilai linearitas dan rentang respon sensor paling baik yaitu pada rentang kelembaban relatif $76 \%-81 \%$, sedangkan untuk sensor yang mempunyai sensitivitas tertinggi pada sensor cladding babi dan sapi dengan panjang kupasan $4 \mathrm{~cm}$ dengan nilai sensitivitas sebesar $0,0075 \mathrm{~V} / \%$ kelembaban relatif.
\end{abstract}

Kata Kunci-Cladding, Gelatin Babi, Gelatin sapi, Serat optik, Sensor kelembaban.

\section{PENDAHULUAN}

$\mathrm{K}$ ELEMBABAN adalah jumlah air yang terkandung didalam suatu zat melalui proses absorpsi atau adsorbs [1]. Jika besarnya kelembaban tidak tepat sesuai kebutuhan maka akan menimbulkan gangguan dan kerusakan sebab kelembaban dapat mempengaruhi proses-proses fisika, kimia dan biologi di alam. Sebagai contoh, mesin-mesin indstri akan mudah berkarat apabila dalam keadaan kelembaban tinggi [2].

Serat optik tidak hanya digunakan sebagai pandu gelombang optik untuk sistem komomunikasi [3], tetapi dapat juga dimanfaatkan untuk membuat sensor. Salah satunya digunakan sebagai sensor kelembaban[2]. Penggunaan serat optik sebagai sensor kelembaban telah banyak dilakukan dengan berbagai macam metode dengan hasil rentang kelembaban relatif yang berbeda-beda [4][5][6] dan [7]. Rentang ini juga dipengaruhi oleh materi apa yang digunakan sebagai pengganti cladding pada serat optik sebagai sensor kelembaban[2]. Untuk itu perlu adanya inovasi bahan dalam penggantian cladding sebagai sensor. Bahan yang dipilih merupakan bahan yang mempunyai sifat optis [8]. Salah satu bahan yang mempunyai sifat optis yaitu gelatin. Gelatin mempunyai sifat dapat membentuk gel [9]. Gelatin merupakan

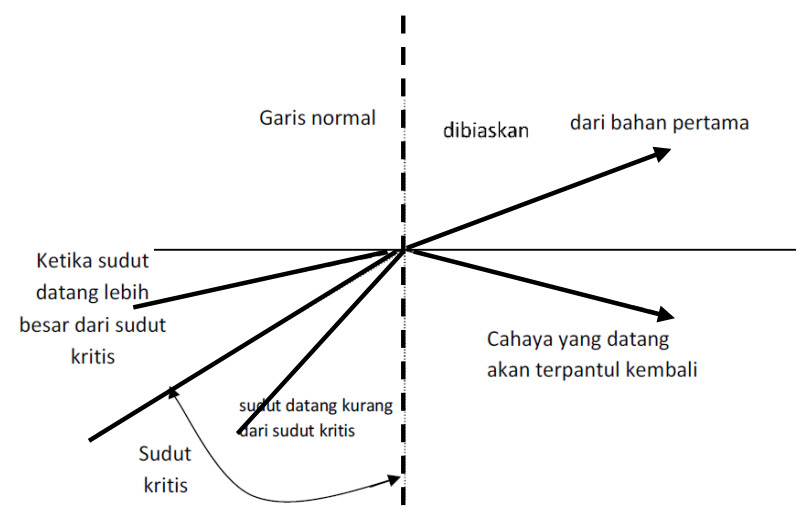

Gambar 1. Proses terjadinya pemantulan dalam total pada serat optic.

sistem koloid padat (protein) dalam cairan (air) sehingga pada suhu dan kadar air yang tinggi gelatin mempunyai kemampuan cairan yang disebut fase sol atau hidrosol, sebaliknya pada suhu dan kadar air yang rendah gelatin mempunyai kemampuan yang lebih kasar atau lebih pekat strukturnya, yang disebut fase gel. Pemanasan dan penambahan air akan mengubah gelatin menjadi fase sol, sebaliknya pendinginan dan pengurangan air akan mengubah gelatin menjadi fase gel [10]. Prinsipnya bahan gel gelatin akan mengalami pembengkakan ketika menyerap air [11], sehingga kerapatannya berkurang yang mengakibatkan sifat optiknya juga berubah, yaitu nilai indeks bias [12] berkurang terhadap jumlah air yang diserap [2].

Pada penelitian ini jenis serat optic yang digunakan adalah multimode step index [13]. Pada serat optik ini cahaya yang terpandu akan mengalami banyak pemantulan sehingga energi cahaya yang dipancarkan sebagian akan berkurang atau hilang. Pada serat optik ini berkas sinar yang dipandu lebih dari satu berkas, sehingga berkas yang dipandu akan melalui jalur yang berbeda-beda dan memiliki panjang lintasan yang berbeda-beda saat di penerima berkas (Gambar 1). Sehingga di bagian detektor cahaya, pulsa yang diterima akan mengalami pelebaran akibat waktu tempuh yang berbeda-beda sehingga penerimaan tidak dalam waktu yang bersamaan, yang disebut dengan dispertion mode [13].

Mekanisme pemanduan gelombang cahaya dalam serat optik didasarkan pada prinsip pemantulan dalam total pada bidang batas core dan cladding sesuai dengan hukum snellius. 


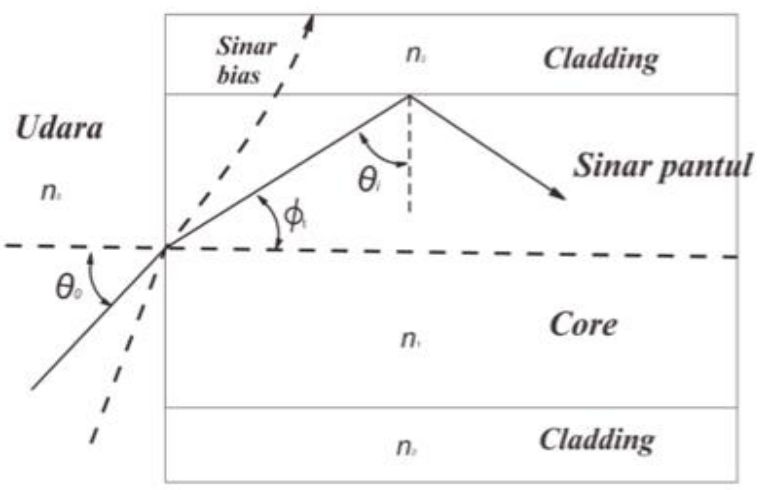

Gambar 2. Ilustrasi numerical aperture.

Penerapan hukum didasarkan pada proses pemantulan dan pembiasan sinar pada bidang batas antara dua medium yang berbeda [8]. Syarat terpandunya gelombang cahaya yaitu indeks bias inti harus lebih besar dari indeks bias cladding dan sudut dating harus lebih besar dari sudut kritis. Ketika cahaya merambat dengan sudut datang yang kurang dari sudut kritis maka cahaya akan dibiaskan keluar dari inti menuju selubung (cladding), akan tetepi jika sudut datang lebih besar dari sudut kritis maka berkas cahaya datang tidak ada yang dibiaskan ke cladding, melainkan semuanya dipantulkan ke dalam core dan inilah yang disebut sebagai pemantulan dalam total [8].

Numerical Aperture adalah suatu ukuran kemampuan serat optik untuk menangkap sinar yang berasal dari sumber optik. Sehingga semakin besar NA menandakan semakin tinggi efisiensi dari suatu sumber optik dalam mengkloping sinarsinar ke dalam serat optic[8].

$$
N A=n_{0} \sin \theta_{0, \max }=\sqrt{n_{1}^{2}-n_{2}^{2}}
$$

Dengan adalah indeks bias udara bernilai 1, $\mathrm{n}_{1}$ adalah indeks bias core dan $\mathrm{n}_{2}$ adalah indeks bias cladding. Berdasarkan Gambar 2, $\theta_{0, \max }$ merupakan batas agar sinar dapat melewati serat optik. Dan sudut inilah yang disebut NA. Sinar tidak dapat melewati serat optik jika datang dengan sudut lebih besar dari $\theta_{0, \max }$. Semua sudut datang yang kurang dari $\theta_{0, \max }$

, max dapat masuk dan melewati didalam serat optik. Nilai NA untuk serat optik step index berkis ar antar 0,2-0,5.

Sensor serat optik adalah jenis sensor optik yang menggunakan serat optik dalam mekanisme pendeteksian, baik sebagai komponen aktif sensor maupun sekedar sebagai pemandu gelombang saja. Sistem sensor optik dilengkapi dengan paling tidak tiga komponen utama, yaitu komponen optoelektronik, link optik dan probe. Komponen optoelektronika meliputi sumber cahaya, detektor optik dan pengolah sinyal. Link optik berupa gelombang serat optik yang berfungsi memandu cahaya ke atau dari bagian penginderaan. Sedangkan probe adalah bagian sensing atau transducing, baik pada bagian di dalam serat optik atau di luar serat optik, yang bertindak sebagai transduser dan berinteraksi

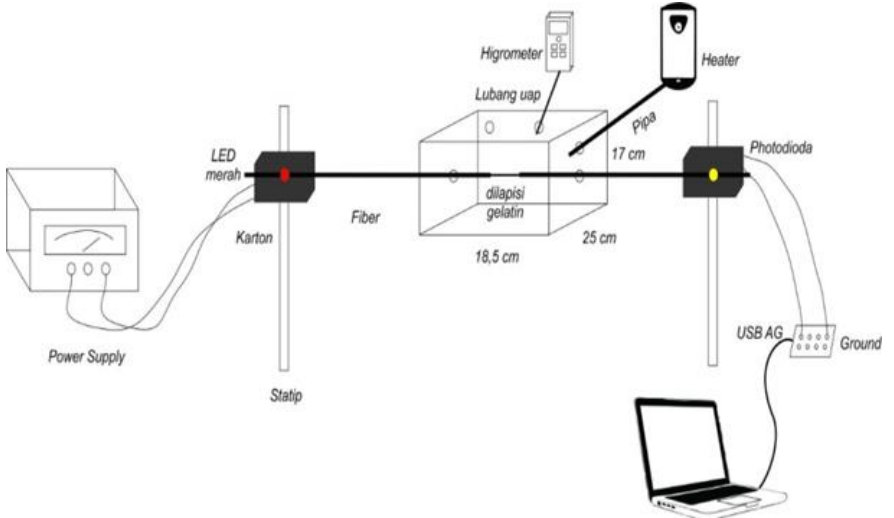

Gambar 3. Skema rangkaian sensor kelembaban.

langsung dengan obyek atau besaran yang diukur [2]. Pada sensor serat optik intrinsik, serat optik disamping sebagai pemandu cahaya juga sekaligus berperan dalam proses penginderaan, dimana terdapat bagian serat optik yang berfungsi sebagai komponen pengindera, baik cladding atau intiny.. Pada sensor tipe ini cahaya tidak pernah meninggalkan serat optik dalam proses penginderaan, jadi proses modulasi terjadi di dalam serat optik, dengan demikian ada bagian serat optik berperan aktif sebagai fungsi sensing (sensing function). Ada beberapa hal yang dapat dilakukan untuk merealisasikan tipe sensor serat optik intrinsik, yaitu dengan atau tanpa memodifikasi struktur serat optik (cladding atau inti). Sebagai contoh dengan memodifikasi cladding dengan material sensitif untuk membangkitkan fenomena optik yang diinginkan seperti medan evanescent. Sensor serat optik intrinsik juga dapat dilakukan melalui prinsip microbending dan macrobending pada serat optik, biasanya diaplikasikan sebagai sensor fisis [1].

\section{METODE PENELITIAN}

\section{A. Pengupasan Cladding Serat Optik}

Proses pembuatan sensor serat optik plastik sebagai sensor kelembaban dengan mengganti clading serat optik menggunakan gelatin babi dan gelatin sapi yaitu serat optik plastik tipe FD 620-10 yang sudah disiapkan dipotong sepanjang $30 \mathrm{~cm}$. Bagian tengah dari serat optik dikupas coatingnya sepanjang $3 \mathrm{~cm}$ dan $4 \mathrm{~cm}$ menggunakan akrilik yang telah didesain sesuai dengan ukuran diameter serat optik. 3. Setelah bagian coating dikupas, bagian cladding yang akan diganti dengan sol-gel gelatin dihilangkan dengan menggunakan cairan aseton. Bagian tengah yang telah terkupas coatingnya direndam dengan larutan aseton kurang lebih selama 30-45 menit untuk menghilangkan claddingnya. Lama waktu lepasnya cladding tergantung dari suhu ruangan yang digunakan. Apabila suhu ruangan tinggi cairan aseton akan cepat menguap, sehingga memperlambat proses pelepasan cladding. Untuk itu diperlukan suhu ruangan sekitar $25^{\circ} \mathrm{C}$ untuk mendapatkan waktu yang lebih efektif untuk menghilangkan cladding serat optik. Untuk mengetahui lapisan cladding asli serat optik sudah terkelupas atau belum dapat diketahui dengan menembakkan laser pada core serat optik. 


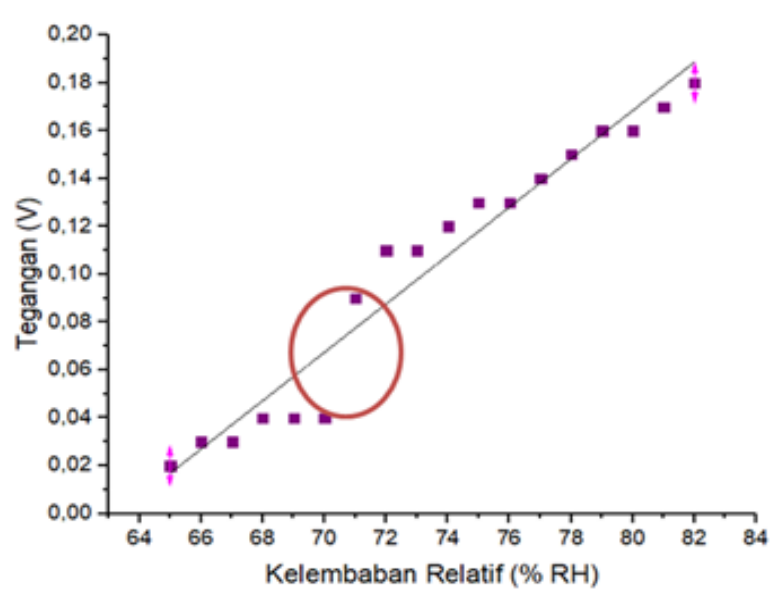

Gambar 4. Hubungan antara nilai RH(\%) terhadap tegangan (V).

Apabila permukaan cahaya pada core terbiaskan seluruhnya berarti lapisan cladding asli sudah lepas seluruhnya. Setelah itu bagian yang sudah tidak ada claddingnya direndam dalam larutan $\mathrm{HNO}_{3}$ dengan kadar 65\% selama 5 menit. Hal ini dikarenakan group $\mathrm{OH}$ yang ada pada permukaan inti harus diaktivasi dengan perlakuan asam. Sehingga grop $\mathrm{OH}$ yang sudah diaktivasi pada permukaan core membentuk ikatan dengan molekul gelatin $+\mathrm{CoCl}_{2}$ untuk menempel pada bagian inti. Setelah itu, serat optik yang telah selesai dari proses perendaman $\mathrm{OH}$ kembali direndam dengan aquades dan dibersihkan menggunakan alkohol.

\section{B. Tahap Pembuatan Lapisan Gel Gelatin}

Pembuatan film tipis sol-gel dimulai dengan mencampurkan 9 gram serbuk gelatin, $30 \mathrm{ml}$ larutan etanol, $30 \mathrm{ml}$ larutan aquades dan $82 \mathrm{mg}$ serbuk $\mathrm{CoCl}_{2}$. Setelah semua bahan dan magnetic stirrer dimasukkan di dalam gelas beker dan diletakkan diatas hot plate. Suhu hot plate diatur sebesar $70^{\circ} \mathrm{C}$. Proses pencampuran dilakukan selama 30 menit. Campuran yang sudah tercampur menggunakan hot plate magnetic stirrer kemudian didinginkan di udara terbuka sampai 1 menit. Pelapisan serat optik menggunakan teknik dip coating. Teknik ini dimulai dengan dengan mencelupkan serat optik pada campuran atau sol gel gelatin yang telah dibuat. Pelapisan dimulai dengan pencelupan selama 10 detik kemudian ditarik. Setelah pelapisan selesai, serat optik dibiarkan pada tekanan atmosfer dan pada suhu kamar selama $24 \mathrm{jam}$.

\section{C.Pembuatan Rangkaian Sensor Kelembaban}

Rangkaian sensor kelembaban serat optik cladding gelatin sapi dan babi dirangkai sesuai skema rangkaian yang terdapat pada Gambar 3 berikut ini. Dari skema rangkian pada Gambar 3.6 dapat dijabarkan prosesnya yang pertama adalah Power supply dihubungkan dengan LED superbright merah agar dapat menyala dengan range sebesar 1,8 volt sampai 2,1 volt. LED dikopling dengan serat optik plastik yang menuju ke dalam humidity chamber. Humidity chamber yang sudah didesain dan terdapat beberapa lubang yaitu lubang untuk tempat masuknya higrometer, serat optik, serta pipa yang

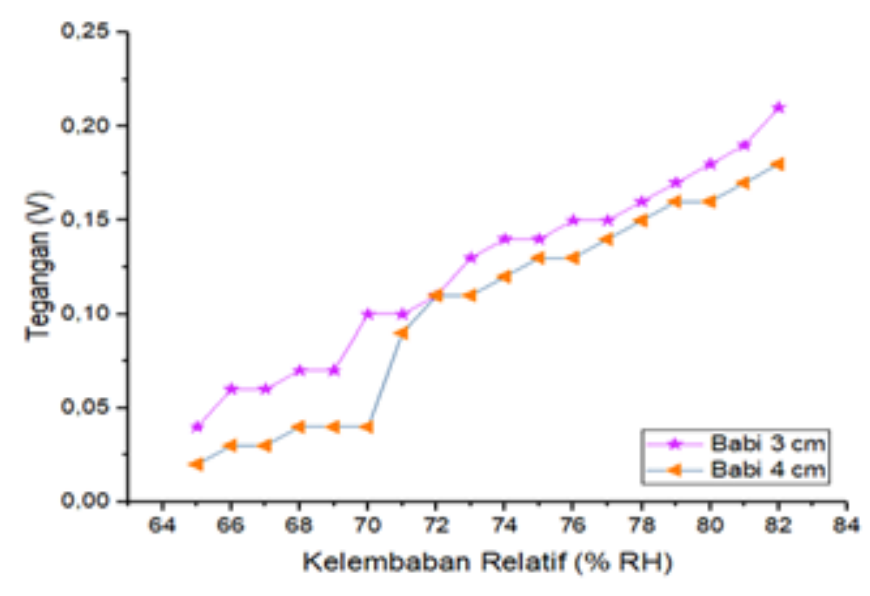

Gambar 5. Hubungan antara nilai $\mathrm{RH}(\%)$ terhadap tegangan (V) pada cladding gelatin babi panjang kupasan $3 \mathrm{~cm}$ dan $4 \mathrm{~cm}$.

terhubung ke heater tempat masuknya uap panas. Sensor serat optik disusun lurus dan terhubung kembali dengan photodioda. Photodioda dicoupling dengan arduino nano yang terhubung dengan laptop.

\section{D.Pengukuran Sensor Kelembaban}

Setelah rangkaian sensor sudah dirangkai sesuai dengan Gambar 3. Kemudian dilakukan pengukuran sensor kelembaban menggunakan serat optik plastik dengan cladding gelatin dengan panjang kupasan yang berbeda yaitu $3 \mathrm{~cm}$, dan $4 \mathrm{~cm}$. Setelah pengukuran dengan gelatin sapi selesai maka dilanjutkan dengan penggunaan gelatin babi. Berikut ini adalah serat optik plastik dengan cladding gelatin sapi untuk panjang $3 \mathrm{~cm}$ diletakkan di dalam chamber.Power supply dinyalakan dan diatur tegangan input sebesar $2,1 \mathrm{~V}$ sesuai dengan range kerja dari LED merah. Diukur \%RH awal kemudian \%RH dinaikkan menggunakan bantuan uap air dari pipa yang terhubung dengan heater. Tegangan keluaran dari photodioda yang berupa sinyal analog dikonversikan menggunakan arduino nano yang terhubung dengan laptop sehingga dapat mengubahnya menjadi data digital dengan bantuan software PLX-DAQ dengan algoritma pemrograman analogreadexcel yang dapat langsung terhubung dengan microsoft excel. Setelah didapatkan data maka diulangi langkah diatas untuk jenis gelatin yang dipakai yaitu babi dan sapi serta variasi panjang kupasan cladding $3 \mathrm{~cm}$ dan $4 \mathrm{~cm}$.

\section{ANALISA DATA DAN PEMBAHASAN}

\section{A. Hasil Penelitian}

Dari Gambar 4 dapat diketahui bahwa sensor mengalami peningkatan hasil tegangan keluaran hal ini disebabkan adanya perubahan indeks bias cladding gelatin akibat pengaruh perubahan nilai kelembaban. Kelembaban ditandai oleh adanya jumlah uap air di udara. Perubahan nilai indeks bias gelatin ditentukan oleh jumlah uap air yang diserap oleh lapisan gelatin. Uap air yang diserap oleh lapisan gelatin akan memasuki rongga-rongga di dalam gelatin yang menyebabakan gelatin membengkak (swelling). Semakin luas bagian permukaan sensor yang dapat menyerap uap air sehingga 


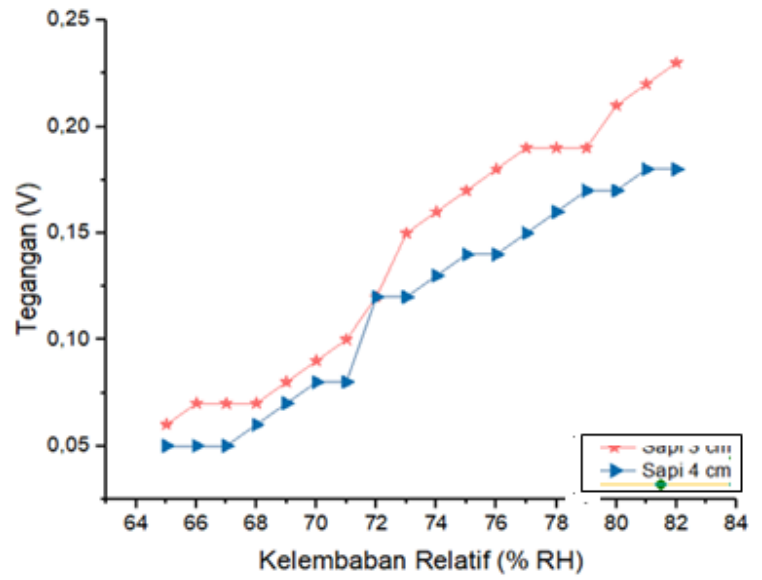

Gambar 6. Hubungan antara nilai RH(\%) terhadap tegangan (V) pada cladding gelatin sapi panjang kupasan $3 \mathrm{~cm}$ dan $4 \mathrm{~cm}$.

seiring dengan pembengkakan gelatin kerapatan gelatin akan berkurang yang berakibat indeks biasnya mengecil. Perubahan indeks bias pada cladding akibat swelling menyebabkan berubahnya sudut kritis pada pemantulan dalam total di dalam inti serat optik (core), akibatnya sebagian energi cahaya terserap oleh cladding keluar dari inti serat secara eksponensial sebagai gelombang evanescent. Penyerapan cahaya yang disebutkan oleh perubahan indeks bias cladding berpengaruh terhadap besarnya intensitas cahaya yang dipandu, besarnya perubahan intensitas cahaya yang dipandu secara tidak langsung akibat perubahan kelembaban. Besarnya energi cahaya yang terserap oleh cladding sebagai gelombang evanescent. Semakin tinggi kelembaban relatif maka penyerapan medan evanescent semakin menurun. Menurunnya penyerapan medan evanescent mengakibatkan cahaya yang terpandu pada serat optik mengalami peningkatan dan pada akhirnya menaikkan tegangan keluaran sensor.

Pada pengukuran sensor ini terdapat rugi daya dimana masukan sensor sebesar 2,1 V menghasilkan keluaran sensor sebesar $(0,02-0,023) \mathrm{V}$ hal ini disebabkan beebrapa hal yaitu hamburan, hamburan yang terjadi adalah hamburan pada sumber cahaya yaitu LED dimana diameter LED lebih besar dari diameter serat optik sehingga sebagian cahaya akan dipandu ke dalam serat optik dan sebagian akan terhambur keluar dari serat optik.

Dari Gambar 4 sampai 7 dapat diketahui sensor hanya dapat digunakan pada pengukuran dengan kenaikan \% kelembaban relatif, sedangkan untuk pengukuran sensor pada penurunan nilai \% kelembaban relatif, sensor tidak dapat dilakukan. Apabila ingin mealukan pengukuran sensor dengan penurunan nilai kelembaban relatif maka perlu melakukan penyusutan pada cladding gelatin.

Grafik yang diperoleh tidak cukup linear untuk rentang nilai kelembaban yang diujikan, yaitu dari $65 \% \mathrm{RH}$ sampai hingga 82\%RH seperti ditunjukkan pada Gambar 4 sampai 7 Namun demikian pada kurva-kurva tersebut ada yang cukup linear sehingga dapat dikatakan rentang ters ebut merupakan rentang terbaik dari sensor tersebut. Dengan mengetahui hal tersebut maka dapat dihitung nilai sensitivitas menggunakan hubungan berikut ini

$$
S=\frac{\Delta V}{\Delta \% R H}
$$

Dengan $\Delta V$ adalah perubahan tegangan keluaran berupa volt dan $\Delta \% R H$ adalah varisi kelembaban yang diujikan. Untuk hasil nilai sensitivitas disajikan pada Tabel 1.

Diperoleh nilai sensitivitas yang berbeda pada kedua gelatin serta panjang kupasannya. Nilai sensitivitas terbesar terdapat pada sensor serat optik cladding sapi dan babi panjang kupasan $4 \mathrm{~cm}$. Hal ini membuktikan bahwa semakin panjang kupasan cladding yang diganti dengan cladding gelatin babi dan sapi maka semakin besar nilai sensitivitasnya. Panjang cladding yang dikupas dan diganti dengan gelatin ini berpengaruh sebab semakin panjang cladding gelatin maka semakin luas juga bidang penyerapan uap air yang ditandai dengan peningkatan nilai kelembaban udara sehingga mengakibatkan nilai indeks bias cladding semakin mengecil. Turunnya nilai indeks bias cladding membuat kedalaman penetrasi mengecil. Semakin kecil kedalaman penetrasi, semakin besar medan evanescent yang terpandu sehingga membuat keluaran sensor menjadi naik. Saat keluaran sensor mengalami kenaikan dengan mendekati linearitas dengan rentang yang panjang maka sensitivitasnya semakin besar.

\section{B. Analisis Pengaruh Panjang Kupasan}

Variasi panjang kupasan yang digunakan pada penelitian ini adalah $3 \mathrm{~cm}$ dan $4 \mathrm{~cm}$. Tegangan keluaran yang diukur pada arduino nano diukur pada setiap perubahan \% RH dimulai dari $\%$ RH yang diukur diawal pengukuran. Rentang RH yang digunakan pada penelitian ini adalah 65\% - 82\%. Berikut merupakan gambar yang membandingkan nilai tegangan keluaran dengan \%RH dari gelatin babi dan sapi pada panjang kupasan $3 \mathrm{~cm}$ dan $4 \mathrm{~cm}$.

Berdasarkan Gambar 5 dan 6 dapat diketahui adanya pengaruh panjang kupasan cladding terhadap tegangan keluaran yang dihasilkan. Pada kedua cladding gelatin sapi dan babi rentang hasil tegangan keluaran pada kupasan $3 \mathrm{~cm}$ lebih besar dibandingkan pada kupasan $4 \mathrm{~cm}$. Hal ini diakibatkan pada proses pengelupasan jaket (coating) terjadi goresan pada inti serat optik sehingga menyebabkan kebocoran cahaya saat dipandu. Serat optik yang hanya tersisa bagian core ini jika diberikan sumber cahaya laser maka akan terjadi kebocoran cahaya sepanjang daerah kupasan. Penggunaan akrilik dan cutter dalam menghilangkan jaket menyebabkan permukaan selubung (cladding) sampai initi (core) tergores yang menyebabkan normal bidang pada permukaan berubah. Peristiwa ini menyebabkan berubahnya nilai sudut kritis pada daerah kupasan. Berubahnya normal bidang permukaan menyebabkan besar sudut datang cahaya terhadap normal bidang berubah sehingga terdapat cahaya yang datang lebih kecil dari pada sudut kritisnya. Akibatnya cahaya yang datang lebih kecil dari sudut kritisnya akan dibiaskan keluar medium inti (core) menuju selubung (cladding) sehingga terjadi kebocoran cahaya. 
Tabel 1.

Nilai sensitivitas sensor kelembaban serat optik

\begin{tabular}{ccc}
\hline \hline Gelatin & $\begin{array}{c}\text { Panjang Kupasan } \\
(\mathrm{cm})\end{array}$ & Sensitivitas(V/\%RH) \\
\hline Babi & 3 & 0,0066 \\
Babi & 4 & 0,0075 \\
Sapi & 3 & 0,0066 \\
Sapi & 4 & 0,0075 \\
\hline \hline
\end{tabular}

\section{KESIMPULAN}

Berdasarkan penelitian yang telah dilakukan dapat diamati hubungan antara RH dengan tegangan keluaran detektor, dapat disimpulkan lapisan cladding gelatin $+\mathrm{CoCl}_{2}$ dapat digunakan sebagai elemen sensor kelembaban, karena sifat optik gelatin babi dan sapi yang sensitif terhadap uap air didapatkan hasil dari pengukuran dapat merespon perubahan kelembaban udara sdari $65 \%-82 \%$ RH. Sensor kelembaban serat optik cladding gelatin babi panjang kupasan $3 \mathrm{~cm}$ merupakan sensor dengan nilai linearitas dan rentang respon paling baik, sedangkan untuk sensor yang mempunyai sensitivitas tertinggi terdapat pada sensor serat optik cladding babi dan sapi dengan kupasan $4 \mathrm{~cm}$ gambar dan tabel telah memenuhi kriteria yang telah disebutkan. Ssensor kelembaban serat optik hanya dapat digunakan pada kenaikan nilai kelembaban relatif.

\section{V.SARAN}

Berapa saran dari peneliti untuk penelitian selanjutnya adalah untuk penelitian selanjutnya, disarankan untuk lebih memvariasi panjang kupasan cladding serat optik, yakni rentang panjang kupasan $5 \mathrm{~cm}$ sampai $8 \mathrm{~cm}$ agar didapatkan nilai sensitivitas yang lebih baik dari serat optik saat pengukuran sensor kelembaban. Penggunaan chamber yang terbuat dari bahan yang dapat menyimpan panas sehingga lebih mudah untuk meningkatkan nilai \%RH. Peningkatan nilai kelembaban relative memakai humidifier. Serta dapat dilakukan variasi gelatin yang digunakan selain babi dan sapi contohnya gelatin ikan.

\section{DAFTAR PUSTAKA}

[1] S. Wayan, M. S. Muntini, and A. M. Hatta, "Pengembangan Sensor Napas Berbasis Serat Optik Plastik dengan Cladding Terkelupas untuk Aplikasi di Bidang Medis," J. Fis. dan Apl., vol. 8, no. 2, 2012.

[2] Akhiruddin, "Pengembangan Probe Sensor Kelembaban Serat Optik dengan Cladding Gelatin," 2006.

[3] Abramczyk, "Fundamentals of Optical Fiber Transmission," Berlin, 2008.

[4] A. Vijayan and et al, "Optical Fiber Based Humidity Sensor Using Co-Polyaniline Clad,” New Delhi, 2008.

[5] B. D. Gupta and et al, "A Novel Probe For A Fiber Optic Humidity Sensor," New Delhi, 2001.

[6] K. Khijwania and et al, "An Evanescent Wave Optical Fiber Relative Humidity Sensor With Enhanced Sensitivity," USA, 2005.

[7] Vidia, "Perancangan Sensor Kelembaban Menggunakan Serat Optik Dengan Cladding Gelatin+CoCl2," Surabaya, 2011.

[8] G. Keiser, Optical Fiber Communications. New York: Mc Graw Hill, 1991.

[9] J. Akhyunul, Tinjauan Kehalalan dan Alternatif Produksi. Malang: UIN Malang Press, 2008.

[10] Gelatin Manufacturers Institute of America, "Gelatin Handbook," USA, 2012.

[11] J. Power, An Introduction To Fiber Optic Systems, 2nd ed. New York: Mc Graw Hill, 1997.

[12] Y. Suematsu, Optical Device And Fiber. Tokyo: OHM, 1982.

[13] M. Yoga, "Rancang Bangun Sistem Transmisi Data Menggunakan Serat Optik Pastik Untuk Pengukuran Suhu," Surabaya, 2011. 